\title{
HUBUNGAN MENGKONSUMSI OBAT HERBAL (JAMU GEPYOK) DENGAN PRODUKSI ASI DI BPS DS. NGUMPAKDALEM KEC. DANDER KABUPATEN BOJONEGORO TAHUN 2017
}

\author{
Fitria Rizky Kurniawati \\ STIKes Insan Cendekia Husada Bojonegoro, Arsen26072015@gmail.com
}

\begin{abstract}
Abstrak
Minat masyarakat Indonesia terhadap terapi komplementer atau pun yang masih tradisional mulai meningkat. Frekuensi dari pemanfaatan terapi alternatif komplementer meningkat pesat di seluruh pelosok dunia. Hasil (Supardi and Susyanty, 2010) menunjukkan penduduk Indonesia yang mengeluh sakit dalam kurun waktu sebulan sebelum survei 30,90\%. Dari penduduk yang mengeluh sakit, persentase terbesar $(65,01 \%)$ memilih pengobatan sendiri menggunakan obat dan atau obat tradisional. Penggunaan obat tradisional dalam upaya pengobatan sendiri terus meningkat dari $15,2 \%$ menjadi 38,3\% selama kurun waktu 7 tahun sejak tahun 2000-2006 (Supardi and Susyanty, 2010). Tujuan penelitian ini adalah untuk mengetahui hubungan mengkonsumsi jamu gepyokan untuk memperlancar ASI di Kabupaten Bojonegoro Tahun 2017. Penelitian ini menggunakan desain penelitian yang digunakan adalah Cross Sectional metode penelitian deskriptif kuantitatif. Berdasarkan tempat penelitian termsuk jenis rancangan penelitian lapangan. Populasi adalah subjek yang memenuhi kriteria yang telah di tetapkan. Populasi dalam penelitian ini adalah 30 ibu menyusui di BPS Ds. Ngumpakdalem Kec. Dander Kab. Bojonegoro Tahun 2017. Analisis merupakan bagian yang sangat penting untuk mencapai tujuan, dimana tujuan pokok penelitian adalah menjawab pertanyaan pertanyaan penelitian dalam mengungkapkan fenomena. Analisa data dalam penelitian ini menggunakan uji chi square. Hasil penelitian menunjukkan hasil $p$ value $0.468>0.05$ yang berarti tidak ada hubungan antara mengkonsumsi jamu gepyok dengan produksi ASI. Tidak ada hubungan penggunaan jamu gepyok dengan produksi ASI di BPS Ds. Ngumpakdalem Kec. Dander Kab. Bojonegoro Tahun 2017.
\end{abstract}

Kata Kunci: jamu Herbal, Produksi ASI

\begin{abstract}
Indonesian society's interest in complementary or traditional therapy is increasing. The frequency of utilization of complementary alternative therapies is increasing rapidly throughout the world. The result of Susenas (2007) shows Indonesians who complain of pain within the month before the $30.90 \%$ survey. Of the residents who complained of illness, the largest percentage $(65.01 \%)$ chose their own treatment using traditional medicines and / or drugs. The use of traditional medicine in self-medication efforts has steadily increased from $15.2 \%$ to $38.3 \%$ over the course of 7 years from 2000-2006 (Supardi, S and Andi Leny, 2010) The purpose of this study is to determine the effect of the use of herbal medicine to facilitate the expansion of breast milk as an effort to reduce the use of conventional medicines in Bojonegoro District in 2017. This research uses Quasy experimental research design technique (quasi experiment). Based on the place of study including the type of field research design. Population is a subject that meets the criteria that have been set. The population in this study were all breastfeeding mothers in 10 Puskesmas in Bojonegoro Regency in 2016. Analysis is a very important part to achieve the goal, where the main purpose of research is to answer the research questions in expressing the phenomenon . Data analysis in this study using chi square test. The results showed $p$ value $0.468>0.05$ which means there is no relationship between the use of herbal uyup - uyup with milk production.
\end{abstract}

Keywords: Herbal Medicinal and Breastmilk Production 


\section{PENDAHULUAN}

Upaya pelayanan kesehatan secara preventif, promotif dan kuratif adalah pengobatan komplementer yang saat ini menjadi pilihan masayarakat (Kostania et al., 2015). Bidan juga berperan dalam upaya peningkatan pengetahuan masyarakat melalui komunikasi, informasi dan edukasi/ pendidikan contohnya perawatan informasi tentang imunisasi, pengawasan ibu nifas persiapan merawat bayi dan menyusui serta pentingnya pemberian ASI ekslusif (Yulifah dkk, 2013). Dari informasi yang diperoleh peneliti pada seminar komplementer yang disampaikan oleh narasumber salah satu kemampuan yang bisa meningkatkan daya jual lulusan kesehatan (Bidan dan Perawat) adalah melalui terapi komplementer (Kostania et al., 2015)

Penyelenggaraan pengobatan komplementer secara umum telah diatur dalam Keputusan Menteri Kesehatan No.1109/Menkes/Per/IX/2007, beberapa diantaranya yang saat ini sudah diterapkan oleh bidan-bidan dan wanita di Indonesia, yaitu: hipnoterapi, penyembuhan spiritual dan doa, yoga, akupresur, pijat urut, aromaterapi, healing dan jamu (Ayuningtyas, 2017). Budaya masyarakat khususnya masyarakat jawa penggunaan jamu uyup-uyup (gepyokan) untuk memperlancar ASI sudah tidak asing kita dengar. Masyarakat banyak beranggapan dengan mengkonsumsi jamu gepyokan akan meningkatkan produksi Asi (Lindberg et al., 1984).

Tujuan penelitian ini untuk mengidentifikasi hubungan obat herbal (jamu gepyok) untuk memperlancar ASI dengan produksi ASI sebagai upaya menurunkan penggunaan obat - obatan konvensial di Kabupaten Bojonegoro 2017.

Data yang diperoleh peneliti dari $7 \mathrm{ibu}$ menyusui mengkonsumsi jamu gepyokan dengan perlanca rproduksi ASI. Dari $\begin{array}{lll}\text { keterangan } & 7 & \text { responden yang }\end{array}$ mengkonsumsi jamu gepyokan mengatakan baawa produksi ASI semakin banyak (payudara selalu terasa penuh). Peneliti mengharapkan dengan adanya manfaat dari penggunaan jamu gepyokan mampu meningkatkan kemampuan bidan khususnya dalam pelayanan komplementer.

\section{METODE PENELITIAN}

Desain penelitian yang digunakan adalah Cross Sectional metode penelitian deskriptif kuantitatif adalah suatu metode penelitian yang dilakukan dengan tujuan utama untuk membuat gambaran tentang 
suatu keadaan secara obyektif (Alimul, 2007).

Populasi dalam penelitian ini adalah semua ibu menyusui di Wilayah Kerja BPS ('E') Ds. Ngumpakdalem Kec. Dander Kab. Kabupaten Bojonegoro Tahun 2017. Pengambilan sampel pada penelitian ini menggunakan purposive sampling.

Penelitian ini memakai analisis bivariat dengan Menggunakan uji chi square (Nursalam, 2003). Variabel bebas dalam penelitian ini adalah Jamu herbal (jamu gepyok) dan variable terikat dalam penelitian ini adalah produksi ASI. Pada penelitian ini peneliti melakukan pengambilan data dengan menggunakan kuesioner. Populasi dalam penelitian ini adalah ibu menyusui dan sampel dalam penelitian ini antara lain: ibu yang bersedia menjadi responden, ibu yang memiliki bayi usia 0-6 bulan, ibu yang mengkonsumsi jamu gepyok minimal 3x seminggu. Pengolahan data Memakai analisis bivariat dengan Menggunakan uji chi square apabila nilai $\mathrm{p}$ value $<0.05$ maka Ho diterima yang berarti ada Hubungan mengkonsumsi Jamu Gepyok dengan Produksi ASI di BPS Eny Wihayati Ngumpakdalem Kec. Dander Kab. Bojonegoro

\section{HASIL PENELITIAN}

Adapun hasil penelitian ini dijelaskan dalam tabel berikut :

Tabel 1. Karakteristik Responden menurut Usia di BPS Eny Wihayati, SST., Ngumpakdalem Kec. Dander Kab. Bojonegoro 2018

\begin{tabular}{|c|c|c|c|}
\hline No & Umur & Jumlah & $\%$ \\
\hline 1 & $\geq 30$ th & 1 & 3,3 \\
\hline 2 & $26-30$ th & 8 & 26,7 \\
\hline 3 & $20-25$ th & 16 & 53,3 \\
\hline 4 & $\leq 20$ th & 5 & 16,7 \\
\hline \multicolumn{2}{|c|}{ Total } & 30 & 100 \\
\hline
\end{tabular}

Dari data usia menunjukkan sebagian besar $(53,3 \%)$ repsonden berusia $26-30$, menurut (Badan Pusat Statistik, 2007) salah satu faktor kelebihan manusia dari makhluk lainnya adalah kemampuan belajar dari pengalaman, terutama pengalaman yang berakhir pada kesalahan (Effendy, 2000). Sejalan dengan Riskesdas (Badan Pusat Statistik, 2007) bahwa usia diatas 35 tahun mempunyai kebiasaan dalam konsumsi jamu sebagai tanaman obat tradisional sehingga umur diatas 35 tahun ini terbiasa memanfaatkan tanaman obat sebagai usaha self medication (Renstra, 2015).

Usia responden menunjukkan usia 26 - 30 tahun sesuai dengan teori yang ada responden sebagian besar responden berusia dibawah 35 tahun, yang berarti responden lebih memilih tidak mengkonsumsi jamu gepyok secara teratur untuk memperlancar ASI. 
Tabel 2 Karakteristik Responden menurut pendidikan di BPS "E" Ngumpakdalem Kec. Dander Kab. Bojonegoro 2018

\begin{tabular}{|c|c|c|c|}
\hline No & Kriteria & Jumlah & $\%$ \\
\hline 1 & SD & 0 & 0 \\
\hline 2 & SMP & 6 & 20 \\
\hline 3 & SMA & 22 & 73,3 \\
\hline 4 & PT & 2 & 6,7 \\
\hline \multicolumn{2}{|c|}{ Total } & 30 & 100 \\
\hline
\end{tabular}

Sebagian besar $(73,3 \%)$ berpendidikan baik (SMA), dari segi pendidikan dan sebagian besar $(73,3 \%)$ responden sudah berpengetahuan baik Hal ini dapat dihubungkan dengan teori yang menyebutkan bahwa tingkat pendidikan yang ditempuh oleh individu merupakan salah satu faktor yang akan mendukung kemampuannya untuk menerima informasi bahwa semakin tinggi tingkat pendidikan seseorang maka makin luas pula cara pandang dan carapikirnya dalam menghadapi suatu keadaan yang terjadi disekitarnya (Nursalam, 2003).

Sehingga tingkat pengetahuan ini dapat dihubungkan dengan tingkat pendidikan responden. Dari hasil penelitian menunjukkan bahwa tidak semua responden mengkonsumsi jamu uyupuyup secara teratur, jika dikaitkan dengan pendidikan responden makan sebagian responden selain mengkonsumsi jamu uyup - uyup juga memilih menggunakan obat - obatan konvensional untuk pelancar ASI dengan alasan lebih praktis. Hal ini sesuai dengan hasil Riskesdas (2013) bahwa semakin tinggi tingkat pendidikan semakin kurang merasakan manfaat penggunaan jamu/tanaman obat (Lindberg et al., 1984)

Tabel 3 Tabel silang mengkonsumsi Jamu Uyup - Uyup dengan Produksi ASI di BPS "E “ Ngumpakdalem Kec. Dander Kab. Bojonegoro 2018

\begin{tabular}{|c|l|c|c|c|}
\hline \multirow{2}{*}{ No } & $\begin{array}{c}\text { Konsumsi Jamu } \\
\text { Gepyok }\end{array}$ & $\begin{array}{c}\text { Lan } \\
\text { car }\end{array}$ & $\begin{array}{c}\text { Tidak } \\
\text { Lan } \\
\text { car }\end{array}$ & $\begin{array}{c}\text { Tota } \\
1\end{array}$ \\
\hline 1 & $\begin{array}{l}\text { Mengkonsumsi } \\
\text { Teratur }\end{array}$ & 9 & 6 & 15 \\
\hline 2 & $\begin{array}{l}\text { Mengkonsumsi } \\
\text { tidak teratur }\end{array}$ & 8 & 7 & 15 \\
\hline \multicolumn{2}{|l|}{ Total } & & & 30 \\
\hline
\end{tabular}

Tabel silang hubungan mengkonsumsi jamu gepyok dengan produksi ASI di BPS “E” Desa Ngumpakdalem Kec. Dander Kab. Bojonegoro 2018

Hasil uji Chi Square menunjukkan nilai $p$ value 0,645 , dari hasil analisa data nilai $\mathrm{p}$ $0,645>0,05$ yang berarti tidak ada hubungan antara mengkonsumsi jamu gepyok dengan produksi ASI.

\section{PEMBAHASAN}

Dari hasil Berdasarkan hasil olah data di dapatkan hasil nilai $p$ value $0.485 \geq 0.05$ yang berarti tidak hubungan antara mengkonsumsi jamu uyup - uyup dengan produksi ASI. Pada penelitian sebelumnya yang pernah dilakukan oleh Retno Kumalasari yang berjudul Pemberian Jamu Uyup - Uyup Terhadap Kelancaran Pengeluaran Produksi ASI 
Pada Ibu Nifas Tahun 2017, dari hasil penelitian Retno Kumala sari menunjukkan terdapat pengaruh pemberian jamu uyup - uyup dengan pengeluaran ASI. Hasil pada penelitian ini tidak sesuai dengan penelitian sebelumnya dan teori sebelumnya hal ini mungkin dikarenakan ada beberapa factor penyebab antara lain: kandungan jamu gepyok yang diminum responden tidak diketahui kandungannya (komposisi setiap penjual jamu berbeda). Responden dalam penelitian ini berbeda dengan responden sebelumnya. Adapun Keterbatasan peneliti antara lain:

1. Peneliti menggunakan instrumen/ kuesioner yang tidak bisa mengungkap lebih jauh atau lebih mendalam tentang penggunaajamu uyup - uyup.

2. Waktu yang dimiliki peneliti masih sangat terbatas (1 bulan), sehingga dalam kriteria insklusi tidak dapat difokuskan pada responden yang benar-benar mengkonsumsi jamu uyup-uyup secara teratur.

\section{SIMPULAN}

Tidak ada hubungan mengkonsumsi obat herbal (jamu gepyok) dengan produksi ASI di BPS Ds. Ngumpakdalem Kec. Dander Kab. Bojonegoro Tahun 2017.

\section{REFERENSI}

Alimul, aziz (2007) Metode Penelitian Kebidanan dan Teknik Analisa Data. jakarta: salemba medika.

Badan Pusat Statistik (2007) 'Survei Sosial Ekonomi Nasional - Pedoman Kor Juli 2007', (Juli).

Kostania, G. et al. (2015) 'Pelaksanaan pelayanan kebidanan komplementer pada bidan praktek mandiri di kabupaten klaten', XII (1).

Lindberg, S. E. et al. (1984) 'Recent Field Studies of Dry Deposition To Surfaces in Plant Canopies.', Proceedings, Annual Meeting - Air Pollution Control Association, 6. doi: 1 Desember 2013.

Nursalam (2003) Konsep dan Penerapan Metodologi Penelitian Ilmu Keperawatan. Jakarta: salemba medika.

Renstra (2015) Kementerian Kesehatan Republik Indonesia, Kementerian Kesehatan RI. Sekretariat $r$ Jenderal. Rencana Strategis Kementerian Kesehatan Tahun Rencana Strategis Kementerian Kesehatan Tahun. doi: 351.077 Ind r.

Supardi, S. and Susyanty, A. L. (2010) 'The Use of Traditional Medicine in Self Medication in Indonesia (Data Analysis of Susenas 2007)', Buletin Penelitian Kesehatan, 38(2), pp. 80-89. Available at: http://bpk.litbang.depkes.go.id/index.ph p/BPK/article/view/100/174. 